\title{
Efficient Production of Exopolysaccharide by Submerged Fermentation of Hypsizygus marmoreus Using a Two-stage pH Control Strategy
}

\author{
Y. Chen, ${ }^{a}$ X. Y. Zhang, ${ }^{a}$ G. N. Xiao, ${ }^{b}$ and H. L. Yanga, ${ }^{a, *}$ \\ aSchool of Life \& Environmental Science, Wenzhou University, Chashan \\ University Town, Wenzhou 325035, China \\ ${ }^{\mathrm{b}}$ Zhejiang Provincial Key Laboratory for Chemical and Biological \\ Processing Technology of Farm Products, Zhejiang University of Science \\ and Technology, 318 Liuhe Road, Hangzhou 310023, China
}

doi: 10.15255/CABEQ.2016.930

Original scientific paper

Received: July 10, 2016

Accepted: November 14, 2017

The effects of culture conditions and $\mathrm{pH}$ values on the exopolysaccharides (EPS) production by Hypsizygus marmoreus were investigated in this work. The results showed that the optimal carbon and nitrogen sources were glucose and yeast extract at concentrations of $30 \mathrm{~g} \mathrm{~L}^{-1}$ and $12.5 \mathrm{~g} \mathrm{~L}^{-1}$, respectively. In constant $\mathrm{pH}$ fermentation, high biomass concentration and the specific cell growth rate were achieved at $\mathrm{pH}$ 6.5, while high EPS concentration and the specific EPS production rate were obtained at $\mathrm{pH} 7.5$, respectively. Based on kinetics analysis, a two-stage $\mathrm{pH}$ strategy was proposed in which $\mathrm{pH}$ was controlled at 6.5 to maintain high cell growth and glucose consumption in the first $48 \mathrm{~h}$, and then shifted to 7.5 for increasing EPS production. The maximal EPS concentration reached $2.31 \pm 0.07 \mathrm{~g} \mathrm{~L}^{-1}$ by applying this strategy. The EPS productivity $\left(0.024 \mathrm{~g} \mathrm{~L}^{-1} \mathrm{~h}^{-1}\right)$ increased $58.94 \%, 172.7 \%$ and $35.73 \%$, respectively, compared with that of the natural $\mathrm{pH}$, and controlling $\mathrm{pH}$ at 6.5 and 7.5 .

\section{Keywords}

Hypsizygus marmoreus, exopolysaccharide, submerged fermentation, kinetics analysis, two-stage $\mathrm{pH}$ strategy

\section{Introduction}

Mushrooms have long been used as a food and medical resource. Modern scientific studies demonstrate that mushrooms are an abundant source of a wide range of bioactive natural products. Polysaccharides are the best-known mushroom-derived substances, and have various biological activities, such as antitumor, immunomodulatory, antihyperlipidemic, hepatoprotective, antioxidative and anti-fatigue effects ${ }^{1-5}$.

Polysaccharides from medicinal mushrooms such as Ganoderma lucidum, G. tsugae, G. applanatum, Cordyceps sinensis, C. militaris have been studied extensively ${ }^{6-10}$, and the research for new bioactive polysaccharide has been extended to other mushrooms. Hypsizygus marmoreus is a popular edible mushroom containing a variety of bioactive substances, such as polysaccharides, proteins, trace elements, essential amino acids, lectins, terpenoids, tocopherols, ascorbic acid, enzymes and dietary fiber $^{11}$, and has been considered as a functional food in East Asia because of its antifungal, antiprolifera-

${ }^{*}$ Corresponding author: H. Yang, Tel.: +86-577-86691013;

Fax: +86-577-86689257; Email: yangh199@163.com tive, immunomodulating, antioxidant and hepatoprotective activities ${ }^{1,11-13}$.

Generally, polysaccharide could be extracted from the fruiting body of mushrooms. However, this is time-consuming, low-productive and economically unviable, and the production rate is insufficient to meet the current market demand. Submerged culture has been a fast alternative method to produce medicinal mushroom mycelia and bioactive compounds, and a large amount of studies have been focusing on the polysaccharide production by growing mushroom mycelium in liquid culture with defined nutrients ${ }^{6-8,14,15}$. A vast range of valuable polysaccharide has been extensively exploited from medicinal mushrooms by submerged culture, such as G. lucidum, Grifola frondosa, C. militaris ${ }^{6-9,16}$. A few works on polysaccharide production have also been carried out by submerged culture of $H$. marmoreus $^{17}$.

To improve polysaccharide production, some techniques such as media optimization ${ }^{16,17}$, repeated-batch fermentation ${ }^{6-8}$, $\mathrm{pH}$-shift, and dissolved-oxygen transfer (DOT)-shift integrated fed-batch fermentation ${ }^{14}$, multi-fed batch ${ }^{18}$ have been performed on the submerged culture of medicinal mushrooms. Mycelial growth and metabolism can be significant- 
ly affected by media composition and other chemical and physical factors in submerged culture, and $\mathrm{pH}$ is one of the vital parameters because it can influence the solubility of salts, the ionic state of substrates, cell membrane function, and metabolite biosynthesis ${ }^{19}$. Various $\mathrm{pH}$ conditions were studied and two-stage $\mathrm{pH}$ strategy had been utilized to enhance the mycelial growth and product biosynthesis in some fungi fermentation ${ }^{14,15,19-21}$. The polysaccharide productivity of Auricularia auricula increased by $93.3 \%$ when culture $\mathrm{pH}$ was controlled at 5.0 in the first $48 \mathrm{~h}$ and then switched to 5.5 compared with that of non-pH control ${ }^{15}$. The maximum concentration of rhamsan gum was $12.83 \%$ higher when the culture $\mathrm{pH}$ of Sphingomonas sp. was controlled at 7.5 during the first $10 \mathrm{~h}$ and then shifted to 7.0 , than that at natural $\mathrm{pH}^{19}$. Investigation suggested that lower $\mathrm{pH}$ supported cell growth of $\mathrm{Au}$ erobasidium pullulans while higher $\mathrm{pH}$ stimulated pullulan synthesis, and maximum pullulan production could be conducted when two-stage $\mathrm{pH}$ strategy was performed ${ }^{20}$. Tang et al. suggested that the $\mathrm{pH}$-shift from 3.0 to 4.5 on day 4 was beneficial to the intracellular polysaccharide production in the cultivation of G. lucidum CGMCC 5.616, and Lee et al. reported that the $\mathrm{pH}$-shift from 3.0 to 6.0 on day 2 was best for extracellular polysaccharide biosynthesis in the fermentation of G. lucidum ASI $7004^{14,21}$.

In this work, the effect of various $\mathrm{pH}$ on polysaccharide production of $H$. marmoreus was systematically investigated. A pH control strategy was proposed to achieve a high concentration and high productivity of polysaccharide in a $5.0 \mathrm{~L}$ fermenter based on kinetic parameters analysis. A two-stage $\mathrm{pH}$ control strategy was established to improve the polysaccharide production and the effectiveness was verified experimentally.

\section{Materials and methods}

\section{Microorganism}

The strain of H. marmoreus WZ019 was obtained from Sanming Institute of Fungi (Sanming, People's Republic of China). The fungus was maintained on potato dextrose agar (PDA) slants at $4{ }^{\circ} \mathrm{C}$ and subcultured every 2 weeks.

\section{Culture media and cultivation conditions}

The inocula were prepared in 500-mL Erlenmeyer flasks containing $150-\mathrm{mL}$ media at $27^{\circ} \mathrm{C}$ for 6 days with shaking at $170 \mathrm{rpm}$. The culture medium contained $\left(\mathrm{g} \mathrm{L}^{-1}\right)$ : glucose 30 , yeast extract 10 , corn powder $10, \mathrm{MgSO}_{4} 0.75, \mathrm{~K}_{2} \mathrm{HPO}_{4} 1.5$.

For carbon and nitrogen sources screening, the inocula were inoculated at $10 \%(\mathrm{v} / \mathrm{v})$ into $500 \mathrm{~mL}$
Erlenmeyer flasks containing $150 \mathrm{~mL}$ media, and flask cultivation was carried out at $27{ }^{\circ} \mathrm{C}$ for 7 days with shaking at $170 \mathrm{rpm}$. The basal fermentation media consisted of $\left(\mathrm{g} \mathrm{L}^{-1}\right)$ : glucose 20 , yeast extract $10, \mathrm{MgSO}_{4}$ 0.75, $\mathrm{K}_{2} \mathrm{HPO}_{4}$ 1.5.

For various $\mathrm{pH}$ investigations, fermentations were carried out in a 5-L fermenter (Winpact FS02VD, USA) with $4.0 \mathrm{~L}$ media. The agitation speed and aeration rate were controlled at $250 \mathrm{rpm}$ and 2 $\mathrm{vvm}$, respectively, $\mathrm{pH}$ was controlled at a fixed level in the range of 4.5-8.5 with addition of either 1 mol L-1 $\mathrm{NaOH}$ or $1 \mathrm{~mol} \mathrm{~L}^{-1} \mathrm{HCl}$.

\section{Analytical methods}

Collected samples were centrifuged at 3000 rpm for $15 \mathrm{~min}$, and the mycelia were collected and washed twice with distilled water. The biomass was weighed after gradual drying at $65^{\circ} \mathrm{C}$ and $105{ }^{\circ} \mathrm{C}$ until a constant weight, and cooled in a desiccator as described by Wan-Mohtar et al. ${ }^{6}$ The supernatant was used for polysaccharide measurement.

The extracellular polysaccharide (EPS) produced by $H$. marmoreus was precipitated by addition of 4 volumes of $95 \%(\mathrm{v} / \mathrm{v})$ ethanol, and then left overnight at $4{ }^{\circ} \mathrm{C}$. The precipitated polysaccharide was collected by centrifugation at 4,000 rpm for $20 \mathrm{~min}$, and washed with $80 \%(\mathrm{v} / \mathrm{v})$ ethanol three times. The polysaccharide content was determined by phenol-sulfuric acid method ${ }^{22}$. Residual glucose concentration was measured by 3,5-dinitrosalicylic acid (DNS) method using glucose as a standard $^{23}$.

\section{Kinetic parameters calculation}

The kinetic parameters were calculated as described by Wan-Mohtar et al. ${ }^{8}$ The specific cell growth rate $\left(\mu, \mathrm{h}^{-1}\right)$, the specific glucose consumption rate $\left(q_{\mathrm{s}} \mathrm{h}^{-1}\right)$, and the specific EPS production rate $\left(q_{\mathrm{p}}, \mathrm{h}^{-1}\right)$ were estimated from the experimental or fitted data of biomass $\left(X, \mathrm{~g} \mathrm{~L}^{-1}\right)$, residual glucose concentration $\left(S, \mathrm{~g} \mathrm{~L}^{-1}\right)$, and EPS concentration $(P$, $\left.\mathrm{g} \mathrm{L}^{-1}\right)$. The cell yield on glucose $\left(Y_{\mathrm{x} / \mathrm{s}}\right)$ and the EPS yield on glucose $\left(Y_{\mathrm{P} / \mathrm{S}}\right)$ were calculated from $\mu, q_{\mathrm{s}}$, and $q_{\mathrm{p}}$. The parameters were respectively calculated by the following definitions, and the calculations were implemented with Microsoft Excel program. Kinetic parameters were subjected to ANOVA by Bonferroni's Post Test using STATISTICA 6.0, and differences at $p<0.05$ were considered significant.

$$
\begin{gathered}
\mu=\frac{1}{X} \frac{\mathrm{d} X}{\mathrm{~d} t}=\frac{1}{X} \lim \frac{\Delta X}{\Delta t} \\
q_{\mathrm{s}}=-\frac{1}{X} \frac{\mathrm{d} S}{\mathrm{~d} t}=-\frac{1}{X} \lim \frac{\Delta S}{\Delta t}
\end{gathered}
$$




$$
\begin{gathered}
q_{\mathrm{p}}=\frac{1}{X} \frac{\mathrm{d} P}{\mathrm{~d} t}=\frac{1}{X} \lim \frac{\Delta P}{\Delta t} \\
Y_{\mathrm{X} / \mathrm{S}}=-\frac{\mathrm{d} X}{\mathrm{~d} S}=\frac{\mu}{q_{\mathrm{s}}} \\
Y_{\mathrm{P} / \mathrm{S}}=-\frac{\mathrm{d} X}{\mathrm{~d} S}=\frac{q_{\mathrm{p}}}{q_{\mathrm{s}}}
\end{gathered}
$$

\section{Results and discussion}

\section{Effect of carbon and nitrogen on the growth and EPS production}

Carbon and nitrogen sources and their concentrations generally play a significant role because these nutrients are directly linked with cell proliferation and metabolite biosynthesis ${ }^{16}$. To identify the best carbon sources for mycelial growth and EPS production, different carbohydrates, i.e., glucose, lactose, xylose, sucrose, fructose, galactose, were tested. As shown in Fig. 1a, glucose was the optimal carbon source for the fermentation of $H$. marmoreus, which was in accordance with the results of Wang et al. ${ }^{17}$ Mycelial growth increased with an increase in initial glucose concentrations between 5 and $40 \mathrm{~g} \mathrm{~L}^{-1}$, whereas the EPS production enhanced insignificantly when the initial glucose concentration was above $30 \mathrm{~g} \mathrm{~L}^{-1}$ (Fig. 1b).

To investigate the effect of nitrogen sources on mycelia growth and polysaccharide production of H. marmoreus, different nitrogen sources (soybean powder, peptone, yeast extract, ammonium sulfate and ammonium nitrate) were examined, and results showed that yeast extract was the optimal nitrogen source at $12.5 \mathrm{~g} \mathrm{~L}^{-1}$ (Figs. 1c-1d).

\section{Time course of polysaccharide fermentation without pH control}

Culture conditions, such as carbon source, nitrogen source, $\mathrm{pH}$, and temperature varies significantly from species to species. Moreover, the efficiency of any biosystem is strictly $\mathrm{pH}$-dependent owing to strong dependence on enzymatic activity and cellular metabolism ${ }^{24}$. Previous research has shown that the preferable initial $\mathrm{pH}$ for cell growth and polysaccharide production by $H$. marmoreus ZJ-029 was $6.5-7^{17}$. Fig. 2 shows the time courses of biomass formation and EPS production by $H$. marmoreus in a 5-L fermenter without $\mathrm{pH}$ control. It was observed that the $\mathrm{pH}$ of culture broth changed from initial 6.5 to 5.14 during the fermentation, and the main stage of $\mathrm{pH}$ decrease was 24-96 h, which was the exponential phase of $H$. marmoreus. Before the $\mathrm{pH}$ decreased to 5.4, the cell growth increased rapidly and reached the maximum of $8.50 \mathrm{~g} \mathrm{~L}^{-1}$ at
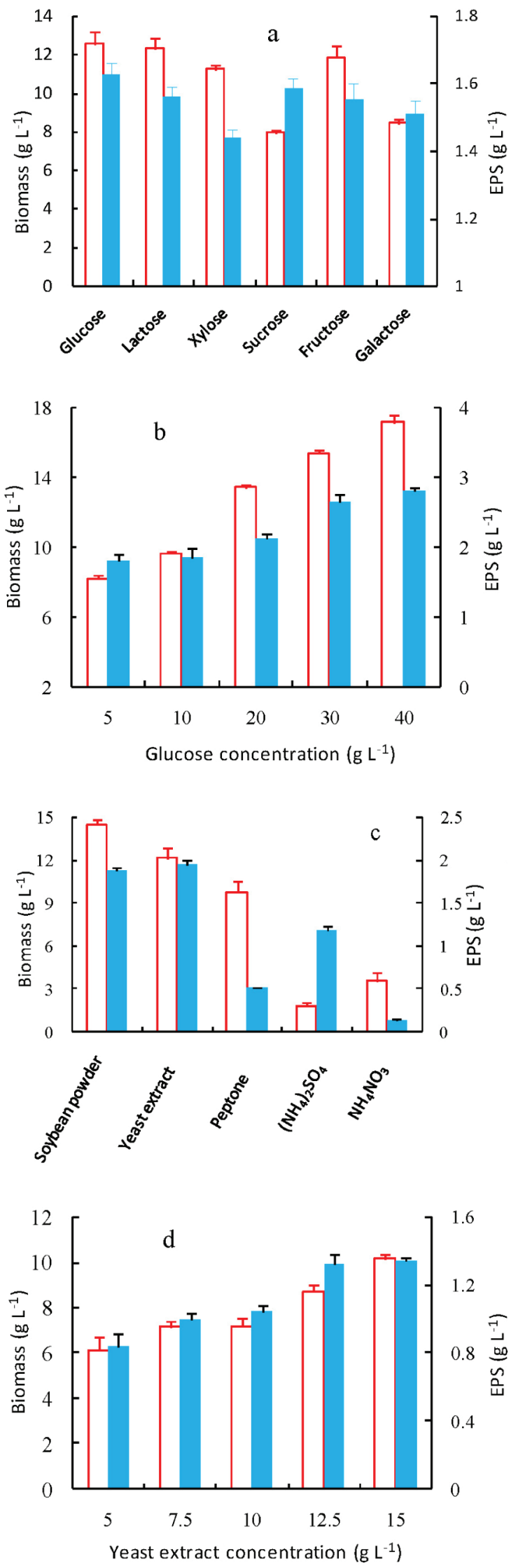

Fig. 1 - Effects of carbon sources (a), glucose concentration (b), nitrogen sources (c) and yeast extract concentration (d) on mycelial growth and EPS biosynthesis by H. marmoreus. EPS (ロ) and biomass (). 


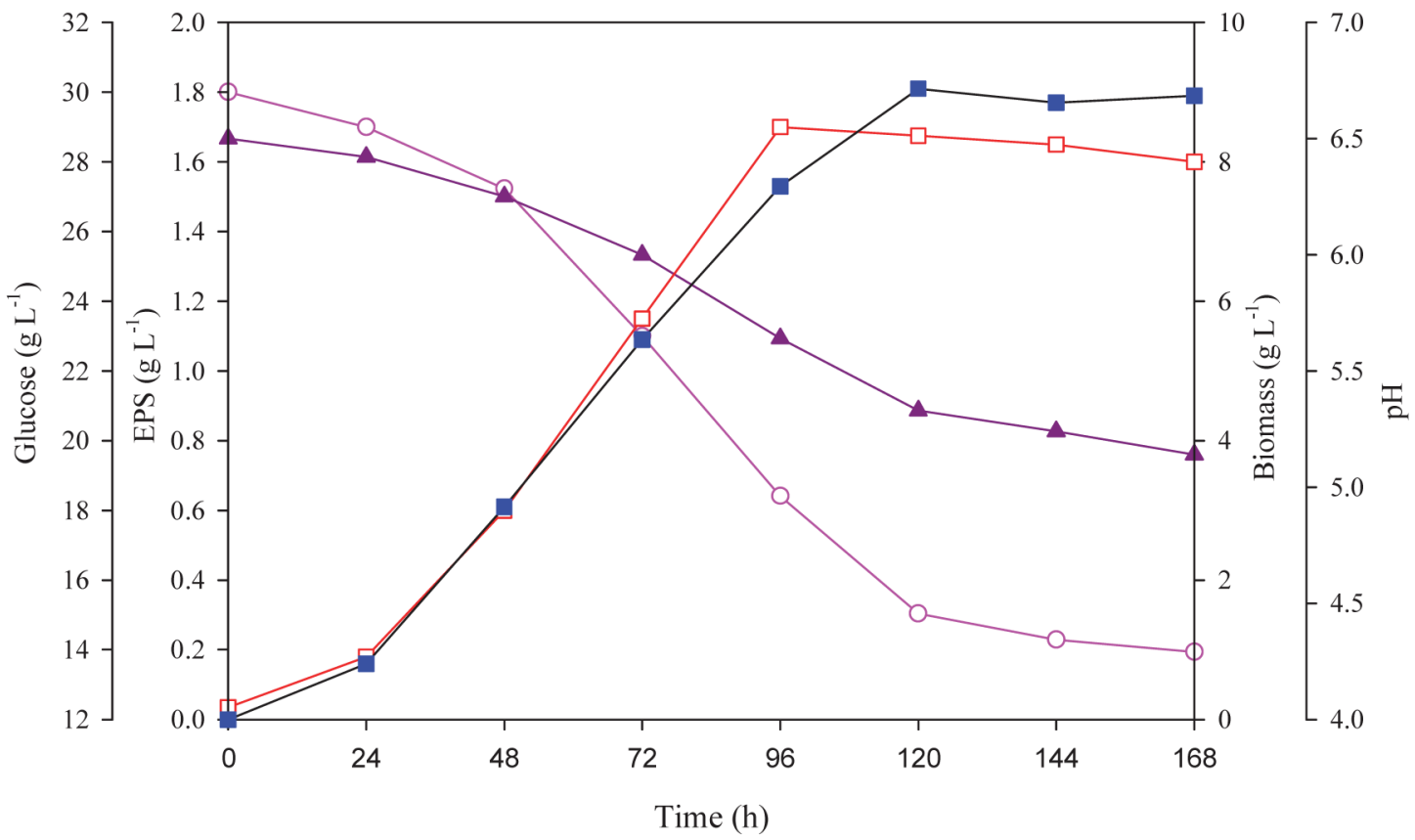

Fig. 2 - Time courses of submerged culture of H. marmoreus in 5-L fermenter under non-pH control.

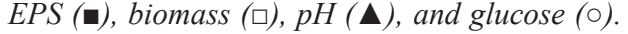

$96 \mathrm{~h}$ of cultivation. After that, the mycelial formation reduced and the biomass concentration decreased slowly. Polysaccharide was produced from $48 \mathrm{~h}$ and the highest concentration reached $1.81 \mathrm{~g} \mathrm{~L}^{-1}$ at $120 \mathrm{~h}$. This indicated that the EPS production was partially correlative to the mycelia growth by H. marmoreus. The glucose consumption trend was in accordance with the cell proliferation and polysaccharide biosynthesis, and the concentration of residual glucose in the fermentation broth reduced sharply from $24 \mathrm{~h}$ to $120 \mathrm{~h}$. The glucose consumption rate decreased after $120 \mathrm{~h}$, and high residual glucose concentration $\left(15.0 \pm 0.43 \mathrm{~g} \mathrm{~L}^{-1}\right)$ was detected at the end of fermentation. Fig. 2 indicates that the $\mathrm{pH}$ in the culture broth was critical in the fermentation of $H$. marmoreus, and the cell growth could be prolonged and the polysaccharide production could be improved by controlling the $\mathrm{pH}$ in the culture broth. Previous researches have shown that high $\mathrm{pH}$ was favorable for some polysaccharide production, such as pullulan ${ }^{20}$, Ganoderma polysaccharide $^{21}$. Similarly, EPS of H. marmoreus was biosynthesized in higher $\mathrm{pH}$ level.

\section{Time courses of polysaccharide fermentation at different $\mathrm{pH}$}

The $\mathrm{pH}$ of fermentation media can influence the morphology of some microbial strains, which may subsequently influence cell growth and metabolite production ${ }^{20,21}$. To explore the effects of controlled $\mathrm{pH}$ on the glucose consumption, mycelia growth and EPS production of $H$. marmoreus, the
$\mathrm{pH}$ was respectively maintained at $\mathrm{pH} 4.5,5.5,6.5$, and 7.5 during the cultivation. As shown in Fig. 3, high $\mathrm{pH}$ was beneficial to mycelial growth and EPS production. The biomass increased when $\mathrm{pH}$ was increased from 4.5 to 6.5 , and the maximum value $\left(10.6 \pm 0.36 \mathrm{~g} \mathrm{~L}^{-1}\right)$ was detected at $\mathrm{pH} 6.5$ after 144 h (Fig. 3a). Consistent with the increase in cell growth, the glucose consumption increased from pH 4.5 to 6.5 (Fig. 3b). However, the desired $\mathrm{pH}$ for polysaccharide biosynthesis and mycelia growth was inconsistent, and the maximum EPS concentration $\left(2.08 \pm 0.07 \mathrm{~g} \mathrm{~L}^{-1}\right)$ was achieved at $\mathrm{pH} 7.5$ after 120 h (Fig. 3c).

\section{Kinetics analysis of EPS production at different $\mathrm{pH}$}

To enhance the EPS concentration and productivity, kinetic parameters of EPS production at different $\mathrm{pH}, \mu, q_{\mathrm{s}}$, and $q_{\mathrm{p}}$ were calculated based on the data in Figs. 3a-3c. As shown in Figs. 3d-3f, the patterns of mycelial growth, glucose consumption, and EPS production under different $\mathrm{pH}$ were significantly different. The maximal mycelial growth rate $(\mu)$ of different constant $\mathrm{pH}$ was all at $24 \mathrm{~h}$ and the values were insignificant $(p>0.05)$ at $\mathrm{pH} 5.5, \mathrm{pH}$ 6.5 and $\mathrm{pH}$ 7.5. However, the mycelia growth rate at $\mathrm{pH} 6.5$ was significantly higher than that at other $\mathrm{pHs}$ at $48 \mathrm{~h}$ (Table 1). The maximal specific cell growth rate and maximal specific glucose consumption rate were respectively observed at $\mathrm{pH} 6.5$ from $24 \mathrm{~h}$ to $48 \mathrm{~h}$ (Figs. 3d and 3e), and the highest cell yield on glucose was achieved at pH 6.5 (Fig. 4a). The $\mathrm{pH}$ values did not affect specific EPS produc- 

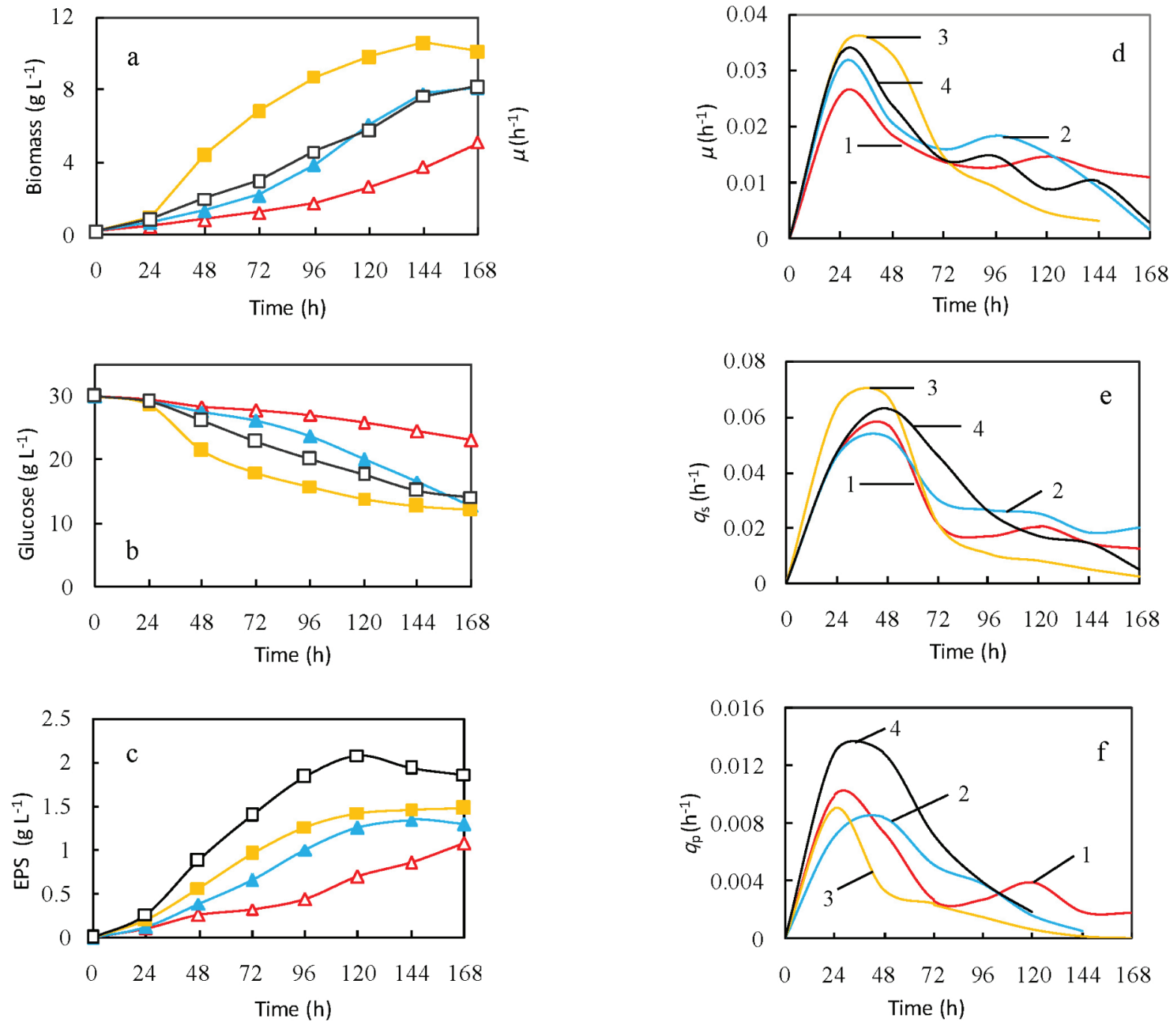

Fig. 3 - Time courses of submerged culture of $H$. marmoreus in 5-L fermenter under different constant pH. pH 4.5 ( $\triangle$ and 1$)$,

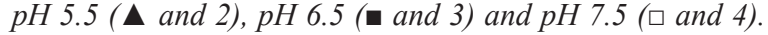
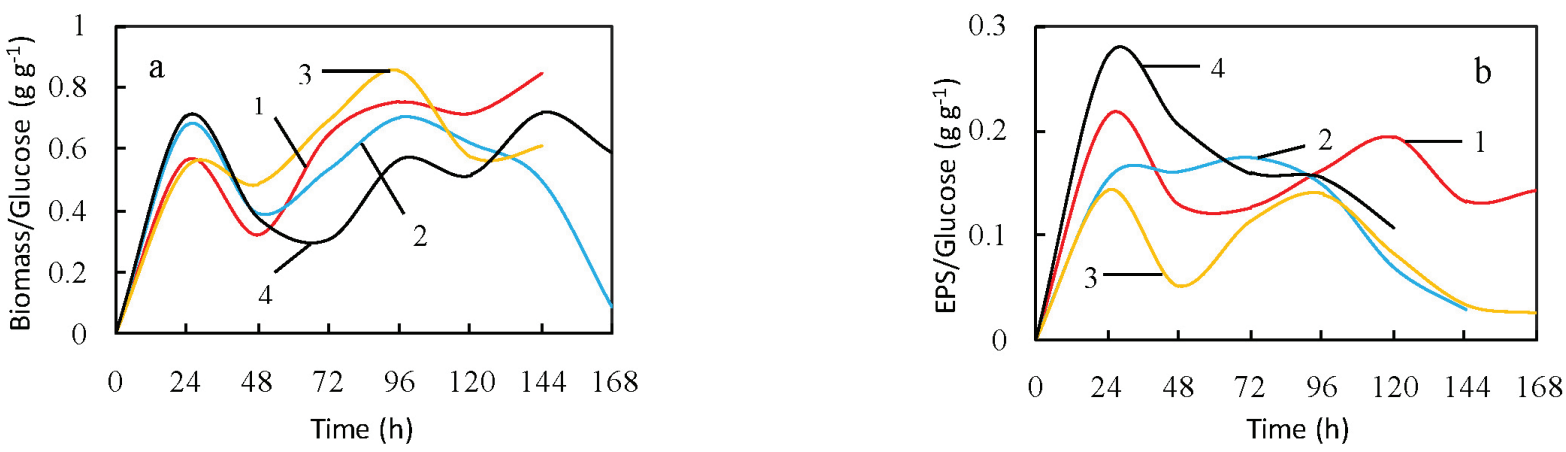

Fig. 4 - Changes in biomass and EPS yields on glucose at different constant pH. pH 4.5 (1), pH 5.5 (2), pH 6.5 (3) and pH 7.5 (4).

tion rate $\left(q_{\mathrm{p}}\right)$ at the initial stage $(0-24 \mathrm{~h})$. The maximal EPS production rate was achieved at $\mathrm{pH} 7.5$ from $24 \mathrm{~h}$ to $48 \mathrm{~h}$, and the EPS yield on glucose $\left(Y_{\mathrm{P} / \mathrm{S}}\right)$ was obtained at $\mathrm{pH} 7.5$ (Figs. 3f and $4 \mathrm{~b}$ ). The concentrations of EPS at $\mathrm{pH} 7.5\left(2.08 \pm 0.07 \mathrm{~g} \mathrm{~L}^{-1}\right)$ increased by $14.92 \%$ compared with that of the natural $\mathrm{pH}\left(1.81 \pm 0.03 \mathrm{~g} \mathrm{~L}^{-1}\right)$.
Based on the analysis of $\mu, q_{\mathrm{s}}$, and $q_{\mathrm{p}}$, it was appropriate to control $\mathrm{pH}$ at 6.5 to maximize the mycelial growth rate and maintain high specific glucose consumption rate in the first $48 \mathrm{~h}$, and then shift $\mathrm{pH}$ to 7.5 to maintain high specific EPS production rate $\left(q_{\mathrm{p}}\right)$ in the submerged culture of $H$. marmoreus. The $\mathrm{pH}$ variation obtained in this study 
Table 1 - Time course of kinetic parameters on the submerged culture of $H$. marmoreus in 5-L fermenter under different constant pH ${ }^{a}$

\begin{tabular}{|c|c|c|c|c|c|c|c|c|c|c|c|c|}
\hline \multirow{2}{*}{$\begin{array}{c}\text { Time } \\
\text { (h) }\end{array}$} & \multicolumn{4}{|c|}{$\mu$} & \multicolumn{4}{|c|}{$q_{\mathrm{s}}$} & \multicolumn{4}{|c|}{$q_{\mathrm{p}}$} \\
\hline & $\mathrm{pH} 4.5$ & pH 5.5 & $\mathrm{pH} 6.5$ & $\mathrm{pH} 7.5$ & $\mathrm{pH} 4.5$ & pH 5.5 & pH 6.5 & $\mathrm{pH} 7.5$ & $\mathrm{pH} 4.5$ & pH 5.5 & pH 6.5 & $\mathrm{pH} 7.5$ \\
\hline 0 & 0 & 0 & 0 & 0 & 0 & 0 & 0 & 0 & 0 & 0 & 0 & 0 \\
\hline 4 & $\begin{array}{l}0.0259 \pm \\
0.0013 b\end{array}$ & $\begin{array}{l}0.0311 \pm \\
0.0014 \mathrm{a}\end{array}$ & $\begin{array}{l}0.0342 \pm \\
0.0013 \mathrm{a}\end{array}$ & $\begin{array}{l}0.0335 \pm \\
0.0003 \mathrm{a}\end{array}$ & $\begin{array}{l}0.0483 \pm \\
0.0116\end{array}$ & $\begin{array}{l}0.0397 \pm \\
0.0135\end{array}$ & $\begin{array}{l}0.0589 \pm \\
0.0063\end{array}$ & $\begin{array}{l}0.0430 \pm \\
0.0207\end{array}$ & $\begin{array}{l}0.0099 \pm \\
0.0004 b\end{array}$ & $\begin{array}{l}0.0071 \pm \\
0.0007 \mathrm{c}\end{array}$ & $\begin{array}{l}0.0090 \pm \\
0.0007 \mathrm{~b}\end{array}$ & $\begin{array}{l}0.0128 \pm \\
0.0003 \mathrm{a}\end{array}$ \\
\hline 48 & $\begin{array}{l}0.0183 \pm \\
0.0009 d\end{array}$ & $\begin{array}{l}0.0204 \pm \\
0.0001 \mathrm{c}\end{array}$ & $\begin{array}{l}0.0327 \pm \\
0.0002 \mathrm{a}\end{array}$ & $\begin{array}{l}0.0237 \pm \\
0.0004 b\end{array}$ & $\begin{array}{l}0.0545 \pm \\
0.0358\end{array}$ & $\begin{array}{l}0.0532 \pm \\
0.0200\end{array}$ & $\begin{array}{l}0.0673 \pm \\
0.0059\end{array}$ & $\begin{array}{l}0.0629 \pm \\
0.0034\end{array}$ & $\begin{array}{l}0.0074 \pm \\
0.0008 b\end{array}$ & $\begin{array}{l}0.0084 \pm \\
0.0002 b\end{array}$ & $\begin{array}{l}0.0034 \pm \\
0.0000 \mathrm{c}\end{array}$ & $\begin{array}{l}0.0129 \pm \\
0.0004 \mathrm{a}\end{array}$ \\
\hline 72 & $\begin{array}{l}0.0137 \pm \\
0.0001\end{array}$ & $\begin{array}{l}0.0159 \pm \\
0.0015\end{array}$ & $\begin{array}{l}0.0147 \pm \\
0.0009\end{array}$ & $\begin{array}{l}0.0139 \pm \\
0.0016\end{array}$ & $\begin{array}{l}0.0213 \pm \\
0.0170\end{array}$ & $\begin{array}{l}0.0302 \pm \\
0.0109\end{array}$ & $\begin{array}{l}0.0215 \pm \\
0.0067\end{array}$ & $\begin{array}{l}0.0459 \pm \\
0.0043\end{array}$ & $\begin{array}{l}0.0027 \pm \\
0.0007 \mathrm{c}\end{array}$ & $\begin{array}{l}0.0052 \pm \\
0.0002 b\end{array}$ & $\begin{array}{l}0.0024 \pm \\
0.0001 \mathrm{c}\end{array}$ & $\begin{array}{l}0.0073 \pm \\
0.0008 \mathrm{a}\end{array}$ \\
\hline 96 & $\begin{array}{l}0.0127 \pm \\
0.0011 b\end{array}$ & $\begin{array}{l}0.0184 \pm \\
0.0003 \mathrm{a}\end{array}$ & $\begin{array}{l}0.0091 \pm \\
0.0003 \mathrm{c}\end{array}$ & $\begin{array}{l}0.0146 \pm \\
0.0007 b\end{array}$ & $\begin{array}{l}0.0168 \pm \\
0.0038 b\end{array}$ & $\begin{array}{l}0.0263 \pm \\
0.0026 a\end{array}$ & $\begin{array}{l}0.0106 \pm \\
0.0021 b\end{array}$ & $\begin{array}{l}0.0258 \pm \\
0.0019 a\end{array}$ & $\begin{array}{l}0.0028 \pm \\
0.0001 b\end{array}$ & $\begin{array}{l}0.0038 \pm \\
0.0003 \mathrm{a}\end{array}$ & $\begin{array}{l}0.0015 \pm \\
0.0001 \mathrm{c}\end{array}$ & $\begin{array}{l}0.0040 \pm \\
0.0002 \mathrm{a}\end{array}$ \\
\hline 120 & $\begin{array}{l}0.0145 \pm \\
0.0005 \mathrm{a}\end{array}$ & $\begin{array}{l}0.0152 \pm \\
0.0002 \mathrm{a}\end{array}$ & $\begin{array}{l}0.0047 \pm \\
0.0009 b\end{array}$ & $\begin{array}{l}0.0088 \pm \\
0.0009 \mathrm{c}\end{array}$ & $\begin{array}{l}0.0207 \pm \\
0.0193\end{array}$ & $\begin{array}{l}0.0249 \pm \\
0.0029\end{array}$ & $\begin{array}{l}0.0081 \pm \\
0.0020\end{array}$ & $\begin{array}{l}0.0170 \pm \\
0.0020\end{array}$ & $\begin{array}{l}0.0039 \pm \\
0.0001 \mathrm{a}\end{array}$ & $\begin{array}{l}0.0017 \pm \\
0.0000 b\end{array}$ & $\begin{array}{l}0.0007 \pm \\
0.0000 \mathrm{c}\end{array}$ & $\begin{array}{l}0.0018 \pm \\
0.0001 b\end{array}$ \\
\hline 144 & $\begin{array}{l}0.0120 \pm \\
0.0003 \mathrm{a}\end{array}$ & $\begin{array}{l}0.0089 \pm \\
0.0010 b\end{array}$ & $\begin{array}{l}0.0031 \pm \\
0.0000 \mathrm{c}\end{array}$ & $\begin{array}{l}0.0100 \pm \\
0.0012 \mathrm{ab}\end{array}$ & $\begin{array}{l}0.0143 \pm \\
0.0051 \mathrm{ab}\end{array}$ & $\begin{array}{l}0.0181 \pm \\
0.0041 \mathrm{a}\end{array}$ & $\begin{array}{l}0.0052 \pm \\
0.0018 b\end{array}$ & $\begin{array}{l}0.0140 \pm \\
0.0031 \mathrm{ab}\end{array}$ & $\begin{array}{l}0.0019 \pm \\
0.0003 \mathrm{a}\end{array}$ & $\begin{array}{l}0.0005 \pm \\
0.0000 b\end{array}$ & $\begin{array}{l}0.0002 \pm \\
0.0001 b\end{array}$ & $\begin{array}{l}-0.0008 \pm \\
0.0001 \mathrm{c}\end{array}$ \\
\hline 168 & $\begin{array}{l}0.0109 \pm \\
0.0012 \mathrm{a}\end{array}$ & $\begin{array}{l}0.0017 \pm \\
0.0008 b\end{array}$ & $\begin{array}{l}-0.0021 \\
0.0002 \mathrm{c}\end{array}$ & $\begin{array}{c} \pm 0.0028 \pm \\
0.0013 \mathrm{~b}\end{array}$ & $\begin{array}{l}0.0125 \pm \\
0.0099 \mathrm{ab}\end{array}$ & $\begin{array}{l}0.0199 \pm \\
0.0031 \mathrm{a}\end{array}$ & $\begin{array}{l}0.0021 \pm \\
0.0019 \mathrm{~b}\end{array}$ & $\begin{array}{l}0.0047 \pm \\
0.0053 \mathrm{ab}\end{array}$ & $\begin{array}{l}0.0018 \pm \\
0.0001 \mathrm{a}\end{array}$ & $\begin{array}{l}-0.0003 \\
0.0001 \mathrm{c}\end{array}$ & $\begin{aligned} & 0.0000 \pm \\
& 0.0001 \mathrm{~b}\end{aligned}$ & $\begin{array}{l}-0.0004 \pm \\
0.0001 \mathrm{c}\end{array}$ \\
\hline
\end{tabular}

${ }^{a}$ The variance of kinetics parameters $\left(\mu, q_{\mathrm{s}}, q_{\mathrm{p}}\right)$ at different $\mathrm{pH}$ was respectively analyzed and the different letters were significantly different at $p<0.05$.

Table 2 -Kinetic parameters of different pH strategy by H. marmoreus in a 5-L bioreactor

\begin{tabular}{l|c|c|c|c|c|c}
\hline \multicolumn{1}{c|}{ Parameters } & Natural $\mathrm{pH}$ & $\mathrm{pH} 4.5$ & $\mathrm{pH} 5.5$ & $\mathrm{pH} 6.5$ & $\mathrm{pH} 7.5$ & $\begin{array}{c}\text { Two-stage } \\
\mathrm{pH} \text { strategy }\end{array}$ \\
\hline Biomass $\left(\mathrm{g} \mathrm{L}^{-1}\right)$ & $8.50 \pm 0.32$ & $5.05 \pm 0.29$ & $8.07 \pm 0.48$ & $10.6 \pm 0.36$ & $8.20 \pm 0.51$ & $12.3 \pm 0.36$ \\
Time of maximal of EPS achieved (h) & 120 & 168 & 144 & 168 & 120 & 96 \\
Concentration of maximal EPS $\left(\mathrm{g} \mathrm{L}^{-1}\right)$ & $1.81 \pm 0.03$ & $1.08 \pm 0.01$ & $1.34 \pm 0.06$ & $1.48 \pm 0.07$ & $2.08 \pm 0.07$ & $2.31 \pm 0.07$ \\
Concentration of residual glucose $\left(\mathrm{g} \mathrm{L}^{-1}\right)$ & $15.0 \pm 0.43$ & $22.9 \pm 0.13$ & $16.6 \pm 0.12$ & $12.1 \pm 0.14$ & $17.6 \pm 0.20$ & $12.0 \pm 0.10$ \\
$Y_{\mathrm{P} / \mathrm{S}}\left(\mathrm{g} \mathrm{g}^{-1}\right)$ & 0.116 & 0.137 & 0.104 & 0.073 & 0.149 & 0.129 \\
$Y_{\mathrm{X} / \mathrm{S}}\left(\mathrm{g} \mathrm{g}^{-1}\right)$ & 0.61 & 0.55 & 0.44 & 0.55 & 0.47 & 0.98 \\
EPS productivity $\left(\mathrm{g} \mathrm{L}^{-1} \mathrm{~h}^{-1}\right)$ & 0.0151 & 0.0064 & 0.0093 & 0.0088 & 0.0173 & 0.0240 \\
\hline
\end{tabular}

was similar to that previously reported by $\mathrm{Wu}$ et $a l .{ }^{15}$, who indicated that a lower initial $\mathrm{pH}(\mathrm{pH} 5.0)$ was beneficial to biomass accumulation, and that a higher initial $\mathrm{pH}(\mathrm{pH} 5.5)$ contributed to EPS production by $A$. auricula.

\section{EPS production with two-stage $\mathrm{pH}$ control strategy}

The $\mathrm{pH}$ level was also considered as a trigger factor for large-scale fermentation system ${ }^{25}$. To achieve maximum metabolite formation, two-stage $\mathrm{pH}$ control strategy had been carried out in the fermentation for the biosynthesis of various products such as polysaccharide ${ }^{14,15,19-21}$, 2,3-butanediol ${ }^{24}$, amino butyric acid $^{25}$, e-poly-L-lysine ${ }^{26}$, arachidonic $\operatorname{acid}^{27}$, cutinase ${ }^{28}$, etc.

The time course of the proposed $\mathrm{pH}$-shift strategy for EPS production by H. marmoreus is shown in Fig. 5. The kinetic parameters of different $\mathrm{pH}$ strategy by $H$. marmoreus in a 5 -L bioreactor are summarized in Table 2. As shown in Table 2, the maximal biomass $\left(12.3 \mathrm{~g} \mathrm{~L}^{-1}\right)$ was achieved after $120 \mathrm{~h}$ under the two-stage $\mathrm{pH}$ control fermentation, which was respectively $44.7 \%, 16.0 \%$ and $50.0 \%$ higher than that of fermentation under natural $\mathrm{pH}$, constant $\mathrm{pH}$ control at $\mathrm{pH} 6.5$ and $\mathrm{pH}$ 7.5. Furthermore, the two-stage $\mathrm{pH}$ control strategy not only considerably improved EPS production but also increased EPS productivity compared with natural $\mathrm{pH}$ and constant $\mathrm{pH}$ control $(\mathrm{pH} 6.5$ and $\mathrm{pH} 7.5)$ cases. The maximal EPS concentration and productivity reached $2.31 \pm 0.07 \mathrm{~g} \mathrm{~L}^{-1}$ and $0.024 \mathrm{~g} \mathrm{~L}^{-1} \mathrm{~h}^{-1}$, which were $27.62 \%$ and $58.94 \%$ higher than that obtained at natural $\mathrm{pH}$ fermentation, respectively. In addition, the residual glucose concentration (12.0 \pm $0.10 \mathrm{~g} \mathrm{~L}^{-1}$ ) in the $\mathrm{pH}$-shift control strategy was much lower than that of natural $\mathrm{pH}$ culture and con- 


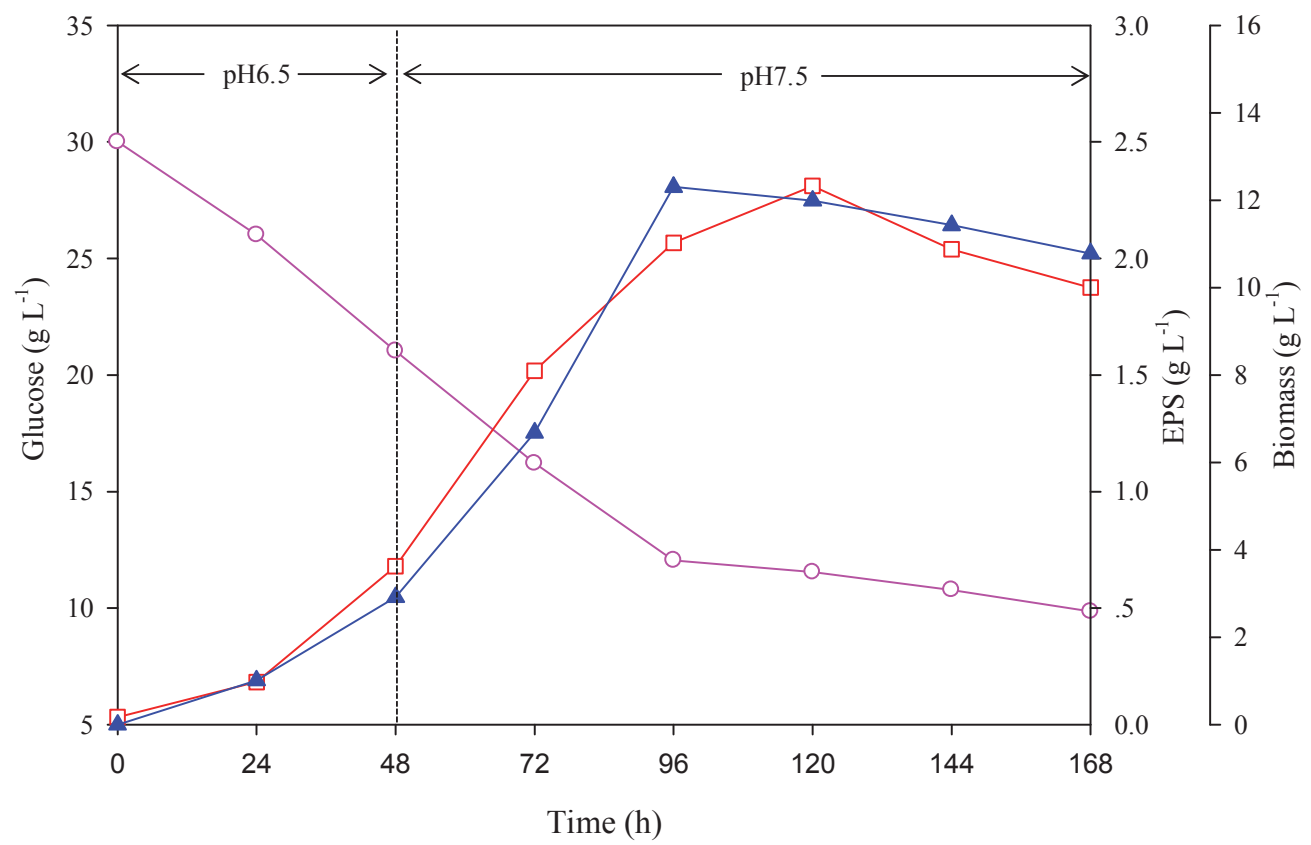

Fig. 5 - Time courses of submerged culture of H. marmoreus in 5-L fermenter under two-stage pH strategy. EPS ( $\mathbf{\Delta})$, biomass ( $\square$ ) and glucose (०).

stant $\mathrm{pH}$ control fermentation at $\mathrm{pH}$ 7.5. These results showed that the proposed $\mathrm{pH}$-shift strategy could efficiently improve the mycelial growth, glucose consumption, and EPS production in submerged culture of $H$. marmoreus.

\section{Conclusions}

The $\mathrm{pH} 6.5$ was suitable for the mycelial growth in submerged culture of $H$. marmoreus WZ019, but $\mathrm{pH} 7.5$ was beneficial to EPS production under the optimal media containing $\left(\mathrm{g} \mathrm{L}^{-1}\right)$ : glucose 30 , yeast extract $12.5, \mathrm{~K}_{2} \mathrm{HPO}_{4} 1.5, \mathrm{MgSO}_{4}$ 0.75. A two-stage controlled $\mathrm{pH}$ strategy for EPS production has been developed based on the kinetic parameters analysis. This method $(\mathrm{pH}$ switching from 6.5 to 7.5 ) was proven to be superior to the constant $\mathrm{pH}$ and the natural $\mathrm{pH}$ cultures in terms of maximal EPS concentration and productivity.

\section{ACKNOWLEDGEMENT}

This work was supported by Zhejiang Department of Science and Technology (Project No. 2015C32131), China.

\section{CONFLICT OF INTEREST}

The authors declare that they have no conflict of interest.

This article contains no studies with human or animal subjects.

\section{References}

1. Yan, P. S., Cao, L. X., Zhang, B. Z., Efficient purification of antiproliferative polysaccharides from Hypsizygus marmoreus with radial flow chromatography, Biotechnol. Prog. 30 (2014) 872 .

doi: https://doi.org/10.1002/btpr.1926

2. Wang, L., Xu, N., Zhang, J., Zhao, H., Lin, L., Jia, S., Jia, L., Antihyperlipidemic and hepatoprotective activities of residue polysaccharide from Cordyceps militaris SU-12, Carbohydr. Polym. 131 (2015) 355.

doi: https://doi.org/10.1016/j.carbpol.2015.06.016

3. Liu, J. Y., Feng, C. P., Li, X., Chang, M. C., Meng, J. L., Xu, L. J., Immunomodulatory and antioxidative activity of Cordyceps militaris polysaccharides in mice, Int. J. Biol. Macromol. 86 (2016) 594.

doi: https://doi.org/10.1016/j.ijbiomac.2016.02.009

4. Mao, G. H., Ren, Y., Feng, W. W., Li, O., Wu, H. Y., Jin, D., Zhao, T., Xue, C. Q., Yang, L. Q., Wu, X. Y., Antitumor and immunomodulatory activity of a water-soluble polysaccharide from Grifola frondosa, Carbohydr. Polym. 134 (2015) 406. doi: https://doi.org/10.1016/j.carbpol.2015.08.020

5. Kan, Y. J., Chen, T. Q., Wu, Y. B., Wu, J. G., Wu, J. Z., Antioxidant activity of polysaccharide extracted from Ganoderma lucidum using response surface methodology, Int. J. Biol. Macromol. 72 (2015) 151. doi: https://doi.org/10.1016/j.ijbiomac.2014.07.056

6. Wan-Mohtar, W. A. A. Q. I., Malek, R. A., Harvey, L. M., McNeil, B., Exopolysaccharide production by Ganoderma lucidum immobilised on polyurethane foam in a repeated-batch fermentation, Biocatal. Agric. Biotechnol. 8 (2016) 24 doi: https://doi.org/10.1016/j.bcab.2016.08.002

7. Wan-Mohtar, W. A. A. Q. I., Kadir, S. A., Saari, N., The morphology of Ganoderma lucidum mycelium in a repeated-batch fermentation for exopolysaccharide production, Biotechnol. Rep. 11 (2016) 2. doi: https://doi.org/10.1016/j.btre.2016.05.005 
8. Wan-Mohtar, W. A. A. O. I., Latif, N. A., Harvey, L. M., McNeil, B., Production of exopolysaccharide by Ganoderma lucidum in a repeated-batch fermentation, Biocatal. Agric. Biotechnol. 6 (2016) 91. doi: https://doi.org/10.1016/j.bcab.2016.02.011

9. Chen, W., Liu, G. Q., Yang, H. D., Wu, Z. C., Yang, H. L., Production and preliminary characterization of antioxidant polysaccharide by submerged culture of culinary and medicinal fungi Cordyceps militaris CICC14013, Int. J. Food Eng. 13 (2017) 20160126. doi: https://doi.org/10.1515/ijfe-2016-0126

10. Chen, Y. C., Chen, Y. H., Pan, B. S., Chang, M. M., Huang, B. M., Functional study of Cordyceps sinensis and cordycepin in male reproduction: A review, J. Food Drug Anal. 25 (2017) 197.

doi: https://doi.org/10.1016/j.jfda.2016.10.020

11. Liu, M., Meng, G., Zhang, J., Zhao, H., Jia, L., Antioxidant and hepatoprotective activities of mycelia selenium polysaccharide by Hypsizygus marmoreus SK-02, Biol. Trace Elem. Res. 2016. doi: https://doi.org/10.1007/s12011-015-0613-z

12. Lee, Y. L., Yen, M. T., Mau, J. L., Antioxidant properties of various extracts from Hypsizygus marmoreus, Food Chem. 104 (2007) 1.

doi: https://doi.org/10.1016/j.foodchem.2006.10.063

13. Zhang, B. Z., Inngjerdingen, K. T., Zou, Y. F., Rise, F., Michaelsen, T. E., Yan, P. S., Paulsen, B. S., Characterisation and immunomodulating activities of exo-polysaccharides from submerged cultivation of Hypsizygus marmoreus, Food Chem. 163 (2014) 120.

doi: https://doi.org/10.1016/j.foodchem.2014.04.092

14. Tang, Y. J., Zhang, Y. J., Zhong, J. J., Performance analyses of a pH-shift and DOT-shift integrated fed-batch fermentation process for the production of ganoderic acid and Ganoderma polysaccharides by medicinal mushroom Ganoderma lucidum, Bioresour. Technol. 100 (2009) 1852. doi: https://doi.org/10.1016/j.biortech.2008.10.005

15. Wu, J., Ding, Z. Y., Zhang, K. C., Improvement of exopolysaccharide production by macro-fungus Auricularia auricula in submerged culture, Enzyme Microbial. Technol. 39 (2006) 743.

doi: https://doi.org/10.1016/j.enzmictec.2005.12.012

16. Yang, H. L., He, G. Q., Influence of nutritional conditions on exopolysaccharide production by submerged cultivation of the medicinal fungus Shiraia bambusicola, World J. Microbiol. Biotechnol. 24 (2008) 2903. doi: https://doi.org/10.1007/s11274-008-9832-1

17. Wang, P., Shi, J., Zhu, Y., Yang, B., Du, S., Optimal conditions for the growth and polysaccharide production by Hypsizygus marmoreus in submerged culture, J. Food Process Preserv. 33 (2009) 454. doi: https://doi.org/10.1111/j.1745-4549.2008.00267.x
18. Zhu, L. W., Zhong, J. J., Tang, Y. J., Multi-fed batch culture integrated with three-stage light irradiation and multiple additions of copper ions for the hyper-production of ganoderic acid and Ganoderma polysaccharides by the medicinal mushroom Ganoderma lucidum, Process Biochem. 45 (2010) 1904.

doi: https://doi.org/10.1016/j.procbio.2010.03.010

19. Ying, X. X., Ping, Z., Sha, L., Ye, C. X., Zhong, Y., Hong, X., Production of rhamsan gum using a two-stage $\mathrm{pH}$ control strategy by Sphingomonas sp. CGMCC 6833, Appl. Biochem. Biotechnol. 172 (2014) 168. doi: https://doi.org/10.1007/s12010-013-0492-8

20. Xia, Z., Wu, S., Pan, S., Effect of two-stage controlled $\mathrm{pH}$ and temperature on pullulan production by Auerobasidium pullulans, Carbohydr. Polym. 86 (2011) 1814. doi: https://doi.org/10.1016/j.carbpol.2011.06.087

21. Lee, K. M., Lee, S. Y., Lee, H. Y., Bistage control of $\mathrm{pH}$ for improving exopolysaccharide production from mycelia of Ganoderma lucidum in an airlift fermentor, J. Biosci. Bioeng. 88 (1999) 646. doi: https://doi.org/10.1016/S1389-1723(00)87094-2

22. Dubois, M., Gilles, K. A., Hamilton, J. K., Rebers, P. A., Smith, F., Colorimetric method for determination of sugar and related substances, Anal. Chem. 28 (1956) 350. doi: https://doi.org/10.1021/ac60111a017

23. Miller, G. L., Use of dinitrosalicylic acid reagent for determination of reducing sugar, Anal. Chem. 31 (1959) 426. doi: https://doi.org/10.1021/ac60147a030

24. Priya, A., Dureja, P., Talukdar, P., Rathi, R., Lal, B., Sarma, P. M., Microbial production of 2,3-butanediol through a two-stage $\mathrm{pH}$ and agitation strategy in $150 \mathrm{~L}$ bioreactor, Biochem. Eng. J. 105 (2016) 159. doi: https://doi.org/10.1016/j.bej.2015.09.016

25. Peng, C. L., Huang, J., Hu, S., Zhao, W. R., Yao, S. J., Mei, $L$. H., A Two-stage $\mathrm{pH}$ and temperature control with substrate feeding strategy for production of gamma-amino butyric acid by Lactobacillus brevis CGMCC 1306, Chin. J. Chem. Eng. 21 (2013) 1190. doi: https://doi.org/10.1016/S1004-9541(13)60568-6

26. Chen, X. S., Li, S., Liao, L. J., Ren, X. D., Li, F., Tang, L., Zhang, J. H., Mao, Z. G., Production of e-poly-L-lysine using a novel two-stage $\mathrm{pH}$ control strategy by Streptomyces sp. M-Z18 from glycerol, Bioprocess Biosyst. Eng. 34 (2011) 561 doi: https://doi.org/10.1007/s00449-010-0505-8

27. Li, X., Lin, Y., Chang, M., Jin, Q., Wang, X., Efficient production of arachidonic acid by Mortierella alpina through integrating fed-batch culture with a two-stage $\mathrm{pH}$ control strategy, Bioresour. Technol. 181 (2015) 275. doi: https://doi.org/10.1016/j.biortech.2015.01.009

28. Du, G. C., Zhang, S. L., Hua, Z. Z., Zhu, Y., Chen, J., Enhanced cutinase production with Thermobifida fusca by two-stage pH control strategy, Biotechnol. J. 2 (2007) 365. doi: https://doi.org/10.1002/biot.200600122 